\title{
Mercury (Hg)-Resistant Bacteria in Hg-Polluted Gold Mine Sites of Bandung, West Java Province, Indonesia
}

\author{
SITI KHODIJAH CHAERUN ${ }^{1,2} *$, SAKINAH HASNI ${ }^{1}$, EDY SANWANI $^{3}$, \\ AND MAELITA RAMDANI MOEIS ${ }^{4}$
}

\begin{abstract}
${ }^{1}$ Laboratory of Biogeosciences, Mining and Environmental Bioengineering, Research Division of Genetics and Molecular Biotechnology, School of Life Sciences and Technology, Institut Teknologi Bandung, Jalan Ganesha 10, Bandung 40132, Indonesia;

${ }^{2}$ Center for Life Sciences, Institut Teknologi Bandung, Indonesia

${ }^{3}$ Department of Metallurgical Engineering, Faculty of Mining and Petroleum Engineering, Institut Teknologi Bandung, Jalan Ganesha 10, Bandung 40132, Indonesia;

${ }^{4}$ Research Division of Genetics and Molecular Biotechnology, School of Life Sciences and Technology, Institut Teknologi Bandung, Jalan Ganesha 10, Bandung 40132, Indonesia
\end{abstract}

In the present study, ten mercury-resistant heterotrophic bacterial strains were isolated from mercurycontaminated gold mine sites in Bandung, West Java Province, Indonesia. The bacteria (designated strains SKCSH1- SKCSH10) were capable of growing well at 200 ppm of $\mathrm{HgCl}_{2}$ except for strain SKCSH8, which was able to grow at $550 \mathrm{ppm} \mathrm{HgCl}_{2}$. The bacteria were mesophilic and grew optimally at $1 \% \mathrm{NaCl}$ at neutral $\mathrm{pH}$ with the optimal growth temperature of $25-37^{\circ} \mathrm{C}$. Phenotypic characterization and phylogenetic analysis based on the $16 \mathrm{~S}$ rRNA gene sequence indicated that the isolates were closely related to the family Xanthomonadaceae, Aeromonadaceae, and Pseudomonadaceae and they were identified as Pseudomonas spp., Stenotrophomonas sp., and Aeromonas sp. Eight bacterial strains were shown to belong to the Pseudomonas branch, one strain to the Stenotrophomonas branch and one strain to the Aeromonas branch of the $\gamma$-Proteobacteria. Phylogeny based on their 16SrRNAgene sequences indicated that four of the isolates (SKCSH1, SKCSH4, SKCSH7, SKCSH9) could be classified as representatives of four novel species in the genus Pseudomonas that were allocated to $P$. moraviensis $(96.96 \%$ similarity) and P. plecogossicida $(94.53,96.61$, and $96.73 \%$ similarity). Four other isolates could be allocated to P. plecogossicida (97.57 and $98.66 \%$ similarity) and P. hibiscicola (99.97\% similarity), one isolate to Stenotrophomonas africana (99.69\% similarity), and one other isolate to Aeromonas hydrophila subsp. ranae ( $99.43 \%$ similarity). The findings of this study provide the first information of the phylogenetically-diverse $\mathrm{Hg}$-resistant bacteria in the Hg-polluted sites of Indonesia that may be highly useful for developing in situ bioremediation or detoxification of Hg-contaminated sites in Indonesia.

Key words: 16S rRNA gene sequences, in situ bioremediation, Mercury (Hg), phenotype, phylogenetic analysis

Tujuan penelitian ini adalah untuk mempelajari secara filogenetika bakteri-bakteri heterotrof yang resisten terhadap merkuri $(\mathrm{Hg})$ yang diisolasi dari daerah pertambangan emas yang tercemar $\mathrm{Hg}$ di Bandung, Jawa Barat, Indonesia. Ada 10 isolat bakteri resisten $\mathrm{Hg}$ yang telah diisolasi dari daerah pertambangan tersebut. Kesepuluh strain adalah mesofilik dan mampu tumbuh pada LB medium dengan konsentrasi $\mathrm{HgCl}_{2}$ sampai sekitar $200 \mathrm{mg} \mathrm{L}^{-1}$ (kecuali strain SKCSH8 mampu tumbuh sampai konsentrasi $\mathrm{HgCl}_{2}$ sebesar $550 \mathrm{mg} \mathrm{L}^{-1}$ ) dengan kondisi pertumbuhan optimum: konsentrasi $\mathrm{NaCl} 1 \%$, $\mathrm{pH}$ netral, dan pada kisaran suhu $25-37{ }^{\circ} \mathrm{C}$. Karakterisasi secara fenotip dan analisis sekuen gen 16S rRNA menunjukkan bahwa delapan strain bakteri termasuk dalam genus Pseudomonas, satu strain dalam genus Stenotrophomonas, dan satu strain lagi dalam genus Aeromonas dari kelas $\gamma-$ Proteobacteria. Analisis filogenetika dari sekuen gen 16S rRNA mengindikasikan bahwa ke-empat isolat (SKCSH1, SKCSH4, SKCSH7, SKCSH9) mempunyai peluang sebagai spesies baru dari genus Pseudomonas yaitu Pseudomonas moraviensis (dengan similaritas 96,96\%) dan Pseudomonas plecogossicida (dengan kemiripan 94\%, 53\%, 96,6\%, dan 96,73\%). Empat isolat yang lain mempunyai kesamaan gen $16 \mathrm{~S}$ rRNA sebesar 97,57\% dan 98,66\% terhadap Pseudomonas plecogossicida dan sebesar 99,97\% terhadap Pseudomonas hibiscicola, serta dua isolat lagi mempunyai kesamaan gen 16SrRNAsebesar 99,69\% terhadap Stenotrophomonas africana dan sebesar 99,43\% terhadap Aeromonas hydrophila subsp. ranae. Hasil penelitian ini memberikan informasi pertama tentang keanekaragaman secara filogenetika bakteri resisten $\mathrm{Hg}$ pada lahan yang tercemar $\mathrm{Hg}$ di Indonesia, yang mungkin dapat bermanfaat dalam mengembangkan bioremediasi secara in situ lahan-lahan yang tercemarHg di Indonesia.

Kata kunci: analisis filogenetika, bioremediasi in situ, fenotip, merkuri(Hg), sekuen gen 16S rRNA

Mercury $(\mathrm{Hg})$ pollution is a significant problem in

*Corresponding author; Phone: +62-87878590709;

E-mail:skchaerun@gmail.com. traditional mining, in particular that located in Indonesia, with respect to abandoned $\mathrm{Hg}$ mines and residual $\mathrm{Hg}$ from gold mining operations that largely 
contribute a significant loading of $\mathrm{Hg}$ to the watersheds each year, e.g. traditional gold mining in Bunikasih, Pangalengan, West Java Province, Indonesia. Correspondingly, mercury is known as one of the most toxic heavy metals and its toxicity is due to its ability to bind readily to thiol group of protein, thus inactivating vital cell functions (Wagner-Dobler 2003). Most of the $\mathrm{Hg}$ in the atmosphere is in the form of elemental $\mathrm{Hg}$ $\left(\mathrm{Hg}^{0}\right)$, which is volatile and is oxidized to the mercuric ion $\left(\mathrm{Hg}^{2+}\right)$ as a result of its interaction with ozone in the presence of water (Chiu et al. 2007; Zhu et al. 2008). The main form of $\mathrm{Hg}$ in the aquatic environment is $\mathrm{Hg}^{2+}$ (Green-Ruiz 2006; Ariya et al. 2009; Mason 2009). When both inorganic mercury forms $\left(\mathrm{Hg}^{2+}\right.$ and $\left.\mathrm{Hg}^{\circ}\right)$ are present in aquatic systems, they are converted into highly toxic organic mercury (methylmercury (MeHg)) that is subsequently bioaccumulated through all levels of the food chain (Mason 2009). Thus, the bioaccumulation and biomagnification of mercury in food chains pose a risk to consumers at the upper trophic levels (Garcia-Sanchez et al. 2006; Ni Chadhain et al. 2006; Yang et al.2009).

Importantly, mercury contamination caused by the amalgamation of gold in small-scale gold mine regions is also a current environmental problem worldwide, particularly in the mining areas of developing countries. The mining operations generally involve the extensive use of mercury to recover gold through the amalgamation process (Ambers and Hygelund 2001; Lecce et al. 2007; Tian et al. 2009). The open-pan amalgamation, when pasty amalgam is heated to vaporize the mercury and separate the gold which is left behind, causes leaving residual mercury to be left in the gold mining sites. Up to the present, mercury contamination of stream sediments caused by gold mining operations have been reported on a worldwide basis (Ambers and Hygelund 2001; Miller et al. 2003; Lecce et al. 2007; Tian et al. 2009). Although mercury has been known as an environmental pollutant for many decades, the release of mercury to the environment from anthropogenic sources is of growing concern (US EPA, 2003). In North Sulawesi Province of Indonesia, in 1998 approximately 22000 small-scale gold miners were active and produced an estimated 10 tonnes of gold bullion. The mercury concentration which was employed in this operation reached $1 \mathrm{~kg}$ out of $30 \mathrm{~kg}$ of ore (Ayhuan et al.2003).

From a microbiological standpoint, mercuryresistant bacteria, which include aerobes or facultative anaerobes, are frequently isolated from a variety of environmental niches such as water, soil and sediment
(Barkay et al. 2003; Chiu et al. 2007). They have an essential role in mercury bio-geochemistry and recycling. The mechanism of their mercury resistance is mediated through a cytoplasmic mercuric reductase by which soluble $\mathrm{Hg}^{2+}$ is converted into insoluble $\mathrm{Hg}^{0}$, followed by volatilization of the relatively non-toxic $\mathrm{Hg}^{0}$. The mercuric reductase is encoded by the merA gene (Nascimento and Chartone-Souza 2003; Fantozzi et al. 2009). Essa et al. (2002) reported that several different mechanisms can make microbes able to survive in the presence of high concentrations of $\mathrm{Hg}$. By having evolved resistance mechanisms to detoxify several chemical forms of mercury, resistant microbes may play an important role in mercury biogeochemistry in mercury-contaminated environments (Dzairi et al. 2004; Gustin and Stamenkovic 2005; Ni Chadhain et al. 2006). Thus, it is expected that exploration of mercury-resistant microbes may potentially be beneficial for detoxifying mercurycontaminated sites.

Hence, the aim of this work was to study the phylogenetic diversity of indigenous $\mathrm{Hg}$-resistant bacterial strains at a traditional gold mine of Indonesia combined with phenotypic analysis (the so-called polyphasic characterization). It is expected that the molecular ecological approaches to studying the $16 \mathrm{~S}$ rRNA gene would exhibit the presence of phylogenetically novel bacterial sequences at these sites as well as novel bacterial isolates resistant to $\mathrm{Hg}$. Such information may be highly useful for developing in situ bioremediation or detoxification of $\mathrm{Hg}$ contaminated sites in Indonesia.

\section{MATERIALS AND METHODS}

\section{Study Sites, Sample Collection, and} Physicochemical Analysis. The study site was located at a traditional gold mining in highly $\mathrm{Hg}$-contaminated environment and overburdened site in Bunikasih, Pangalengan, West Java Province, Indonesia. River sediment samples were collected from 20 random positions of the Bunikasih River, Pangalengan (coded as sediment I-IV) and one soil sample from tailings (coded as tailing soil) in November 2009. For river sediment samples, the site was divided into four plots. At each plot one composite mixed sample was obtained by pooling 4-6 sediment samples from random locations throughout the plot. All samples were transferred to the laboratory and stored at $-20{ }^{\circ} \mathrm{C}$ until required for analysis. Sample $\mathrm{pH}$ was measured by potentiometer in suspension $(1: 1 \mathrm{w} / \mathrm{v})$ according to 
DIN ISO 10390 (DIN ISO 1997), and total mercury content was analyzed according to DIN ISO 38414-S (DIN ISO 1983).

Isolation and Cultivation of Mercury (Hg)Resistant Bacteria. Bacterial strains were isolated from both samples (sediment and tailing soil) on Luria Bertani (LB) broth supplemented with three concentrations of $\mathrm{Hg}^{2+}$ as $\mathrm{HgCl}_{2}\left(25,50,100 \mathrm{mg} \mathrm{L}^{-1}\right)$ at pH 7 and supplemented with antifungal $\left(30 \mathrm{mg} \mathrm{L}^{-1}\right.$ nystatin) to prevent fungal growth. The flasks were incubated at room temperature $\left(25{ }^{\circ} \mathrm{C}\right)$ for $4 \mathrm{~d}$ with agitation of $120 \mathrm{rpm}$, and samples were subsequently transferred onto LB agar plates supplemented with 25 mg L ${ }^{-1}$ of $\mathrm{HgCl}_{2}$ using a 4-way streak method. Ten morphologically different colonies were randomly chosen from each type of $\mathrm{Hg}$-amended agar plates and subcultured on Hg-supplemented LB agar six times for 3-4 d to purify the isolates. Eventually, the pure cultures were subcultured onto Hg-amended LB agar plate and $\mathrm{Hg}$-amended LB broth for stock cultures.

Minimum Inhibitory Concentration (MIC) of $\mathbf{H g}^{2+}$. The assay aimed for bacterial growth at the highest $\mathrm{Hg}^{2+}$ concentration in the form of $\mathrm{HgCl}_{2}$. Briefly, bacterial cultures in LB broth were transferred to a fresh medium and supplemented with $\mathrm{HgCl}_{2}$ at concentrations ranging from 25 to $600 \mathrm{mg} \mathrm{L}^{-1}$. The cultures were then incubated at room temperature and their optical density (OD) was measured at the time of inoculation and afterward up to $4 \mathrm{~d}$ with spectrophotometer at $\lambda$ at $600 \mathrm{~nm}$. Minimal inhibitory concentration (MIC) was the minimum $\mathrm{Hg}^{2+}$ concentration that inhibited growth, i.e., no increase in $\lambda$ at $600 \mathrm{~nm}$ in $4 \mathrm{~d}$.

Phenotypic Characterization. Phenotypic characterization was conducted on the analysis of bacterial cell morphology, biochemical tests, tests of the ability to grow on the variations of temperature, salinity, and pH (Cappuccino and Sherman 2005). All strains were tested at $25{ }^{\circ} \mathrm{C}$ for the following key characteristics. Analysis of bacterial cell morphology used Gram stain, endospore staining and capsule staining, where bacteria were viewed routinely by phase contrast microscopy at $\times 1000$ magnification. Biochemical tests included utilization of catalase, oxidase and citrate, indole production, $\mathrm{H}_{2} \mathrm{~S}$ production, MRVP test (Methyl Red-Voges Proskaur), urease test, nitrate reduction and hydrolysis of gelatin, casein, lipid, starch and tween 80 . In addition, tests of the bacterial ability to use different sugars as a carbon source were performed. These included glucose, galactose, fructose, mannosa, arabinose, sucrose, maltose, and lactose. All strains were tested for their ability to grow on LB agar at various temperatures $(4,25,37$, and 50 $\left.{ }^{\circ} \mathrm{C}\right)$ and on LB broth at different $\mathrm{pH}$ values $(3,5,8$, and 10) adjusted by adding $1 \mathrm{~N} \mathrm{HCl}$ or $1 \mathrm{~N} \mathrm{NaOH}$. Tolerance to salinity was determined in Nutrient Agar (NA) supplemented with $0.5,3$, and $5 \% \mathrm{NaCl}$.

Phylogenetic Characterization of Hg-Resistant Bacterial Strains. Chromosomal DNA for phylogenetic characterization was extracted and purified by using the UltraClean ${ }^{\mathrm{TM}}$ Microbial DNA Isolation Kit (MO BIO Laboratories, Inc.) according to the manufacturer's instructions. The 16S rRNA gene was amplified by PCR with primers $27 \mathrm{f}$ (5'AGAGTTTGATCCTGGCTCAG-3') and 1492r (5'GGTTACCTTGTTACGACTT-3') as described previously (Chaerun et al. 2004). The 16S rRNA gene was amplified from genomic DNA by PCR (2720 Thermal Cycler Applied Biosystems) in a final volume of $25 \mu \mathrm{L}$, consisting of $2.5 \mu \mathrm{L}$ of $10 \times$ Kapa Taq buffer, $5 \mu \mathrm{L}$ of $1 \mathrm{mM}$ deoxynucleoside triphosphate (dNTPs), $1 \mu \mathrm{L}$ of $10 \mu \mathrm{M}$ each of primers $27 \mathrm{~F}$ and $1492 \mathrm{R}, 0.1 \mu \mathrm{L}$ of Kapa Taq DNA polymerase, $1 \mu \mathrm{L}$ of the template DNA, and $14.4 \mu \mathrm{L}$ of deionized $\mathrm{H}_{2} \mathrm{O}$. Amplifications were carried out at $95^{\circ} \mathrm{C}$ for $3 \mathrm{~min}, 30$ cycles at $95^{\circ} \mathrm{C}$ for $1 \mathrm{~min}, 56^{\circ} \mathrm{C}$ for $45 \mathrm{~s}, 72^{\circ} \mathrm{C}$ for $1 \mathrm{~min} 30 \mathrm{~s}$, and the final extension for $4 \mathrm{~min}$ at $72^{\circ} \mathrm{C}$. PCR products were checked by $1 \%$ agarose gel electrophoresis and stained with ethidium bromide (EtBr). The amplified products were purified and sequenced by the direct sequencing method at the $1^{\text {st }}$ Base Bioengineering Technology Service Co., Ltd. (Singapore). The sequences of the $16 \mathrm{~S}$ rRNA genes from each isolate were used as query to determine the genus and species of its closest prokaryotic relative using BLASTN (Altschul et al. 1990). Sequences were aligned using CLUSTAL $X$ program (Version 1.83) (Thompson et al. 1994). Phylogenetic trees were inferred by the neighbourjoining method (Saitou and Nei 1987) with the phylogenetic analysis package PAUP* 4.0 (Swofford 2002) and TREEVIEW was utilized to plot the tree topologies. A bootstrap analysis was performed using 1000 trial replications to provide confidence estimates for branch support (Felsenstein 1985). Reference 16S rRNA sequences were obtained from the GenBank that were included in the phylogenetic analysis.

\section{RESULTS}

Sample Characteristics (pH and $\mathrm{Hg}$ Concentration). Sample characteristics were performed to provide a detailed description of sampling 
Table $1 \mathrm{pH}$ and mercury $(\mathrm{Hg})$ concentration of samples

\begin{tabular}{lccccc}
\hline \multirow{2}{*}{ Characteristics } & \multicolumn{5}{c}{ Sampling site } \\
\cline { 2 - 6 } & Sediment I & Sediment II & Sediment III & Sediment IV & Tailing soil \\
\hline $\mathrm{pH}$ & 7.8 & 7.9 & 7.8 & 7.4 & 8.2 \\
$\mathrm{Hg}$ conc. $\left(\mathrm{mg} \mathrm{L}^{-1}\right)$ & 28.4 & 46.1 & 44 & 60.7 & 27.6 \\
\hline
\end{tabular}

Table 2 Mercury-resistant bacterial strains and their minimum inhibitory concentrations (MIC) of $\mathrm{Hg}^{2+}$ from the Bunikasih traditional gold mine, Pangalengan, West Java Province, Indonesia

\begin{tabular}{lcc}
\hline Isolates & ${\mathrm{MIC} \mathrm{of} \mathrm{HCl}_{2}\left(\mathrm{mg} \mathrm{L}^{-1}\right)}$ Sampling Site \\
\hline SKCSH1 & 250 & Tailing soil \\
SKCSH2 & 225 & Sediment II \\
SKCSH3 & 175 & Sediment III \\
SKCSH4 & 225 & Sediment IV \\
SKCSH5 & 100 & Sediment IV \\
SKCSH6 & 60 & Sediment IV \\
SKCSH7 & 80 & Sediment IV \\
SKCSH8 & 550 & Sediment II \\
SKCSH9 & 250 & Sediment IV \\
SKCSH10 & 200 & Sediment IV \\
\hline
\end{tabular}

site conditions with respect to the $\mathrm{pH}$ and $\mathrm{Hg}$ concentration that are listed in Table 1. Both samples (sediments and tailing soil) had slightly alkaline $\mathrm{pHs}$ (7.4-8.2). Both samples were also characterized by high $\mathrm{Hg}$ concentrations (27.6-60.7 $\left.\mathrm{mg} \mathrm{L}^{-1}\right)$, suggesting that the bacteria residing the site might be resistant to $\mathrm{Hg}$. The highest $\mathrm{Hg}$ concentration was found in Sediment IV and the lowest was obtained in the tailing sample (Table 1).

Isolation and Cultivation of Hg-Resistant Bacteria and Their Minimum Inhibitory Concentrations (MIC) of $\mathbf{H g}^{2+}$. Of the sediment and tailing soil samples, ten morphologically different bacterial colonies were successfully isolated and they were designated as strains SKCSH1-SKSH10 (Table 2). Only one isolate was obtained from tailing soil sample and from sediment III. The more highly polluted samples (sediment II and IV) had the highest number of mercury-resistant aerobic heterotrophs (Table 2). Two isolates (strains SKCSH2 and SKCSH8) were recovered from sediment II and six isolates (strains SKCSH4-7 and SKCSH9-10) from sediment IV whose sediment mercury concentrations were 46.1 and $60.7 \mathrm{mg} \mathrm{L}^{-1}$, respectively. In the case of the tailing soil, only one isolate was identified due to the appearance of the same colonies on agar plates. Moreover, no Hg-resistant bacterial strains were able to be isolated from sediment I. The failure to isolate bacterial strains in this sample was because the colonies growing on agar plates were dominated by fungal colonies (data not shown). A high level of resistance to $\mathrm{HgCl}_{2}$ was noted with all bacterial strains, capable of growing in the presence of at least $25 \mathrm{mg} \mathrm{L}^{-1}$ of $\mathrm{HgCl}_{2}$ with the most resistant strain growing in the presence of $550 \mathrm{mg} \mathrm{L}^{-1}$ of $\mathrm{HgCl}_{2}$ (Table 2). Of the ten isolates, six isolates were able to grow at $\geq 200 \mathrm{mg} \mathrm{L}^{-1}$ of $\mathrm{HgCl}_{2}$ (one strain was highly resistant to $\mathrm{HgCl}_{2}$ of $550 \mathrm{mg} \mathrm{L}^{-1}$, while the four remaining isolates grew below $200 \mathrm{ppm}$ of $\mathrm{HgCl}_{2}$ ). Strain SKCSH8 (from sediment II) was the most resistant strain to $\mathrm{HgCl}_{2}$. The most sensitive strains were found for strains SKCSH6 and SKCSH7 (from sediment IV), which were inhibited by 60 and 80 $\mathrm{mg} \mathrm{L}^{-1}$ of $\mathrm{HgCl}_{2}$, respectively (Table 2).

Phenotypic Characterization of $\mathrm{Hg}$-Resistant Bacteria. Phenotypic characteristics of all ten $\mathrm{Hg}$ resistant bacterial strains are given in Table 3. All ten strains (SKCSH1 SKCSH10) were Gram-negative and had no capsule. Cells of all strains were rod-shaped in all growth phases in both liquid and agar media, except for strains SKCSH7 and SKCSH8 which were coccoid and curved-rods, respectively. When they were grown on LB agar, colonies of all strains were white, except that strain SKCSH7 which was yellow-colored. Catalase activity was present for all strains, while oxidases were only present for strains SKCSH1, SKCSH4, SKCSH7, SKCS8, and SKCSH9. Negative results were obtained for indole production, $\mathrm{H}_{2} \mathrm{~S}$ production from thiosulfate, and urease activity, and positive results for VP reaction for all strains. Assays for MR reduction were negative for all strains with the exception of strains SKCSH1 and SKCSH4. Citrate utilization was also negative for all strains except for strains SKCSH1, SKCSH2, SKCSH4, and SKCSH9. Hydrolysis of lipid and tween 80 was detected for all bacterial strains, while none of them could hydrolyze gelatin with the exception of strain SKCSH2. Of the ten strains, only strains SKCSH2 and SKCSH7 were able to hydrolyze casein. Likewise, only four strains (SKCSH2, SKCSH4, SKCSH8, and SKCSH9) were capable of reducing nitrate to nitrite. $\mathrm{NaCl}$ tolerance was also studied with $\mathrm{NaCl}$ added at final 
Table 3 Phenotypic characteristics of mercury-resistant bacterial strains isolated from the Bunikasih traditional gold mine, Pangalengan, West Java Province, Indonesia

\begin{tabular}{|c|c|c|c|c|c|c|c|c|c|c|}
\hline \multirow{2}{*}{ Characteristics } & \multicolumn{10}{|c|}{ Isolates } \\
\hline & 1 & 2 & 3 & 4 & 5 & 6 & 7 & 8 & 9 & 10 \\
\hline Gram & - & - & - & - & - & - & - & - & - & - \\
\hline Capsules & - & - & - & - & - & - & - & - & - & - \\
\hline Cell shape & rods & rods & $\operatorname{rods}$ & $\operatorname{rods}$ & rods & rods & cocci & curved rods & rods & rods \\
\hline Colony colour & white & white & white & white & white & white & yellow & white & white & white \\
\hline Catalase Activity & + & + & + & + & + & + & + & + & + & + \\
\hline Oxidase Activity & + & - & - & + & - & - & + & + & + & - \\
\hline \multicolumn{11}{|l|}{ IMViC T est: } \\
\hline Indole Production & - & - & - & - & - & - & - & - & - & - \\
\hline MR Reduction & + & - & - & + & - & - & - & - & - & - \\
\hline VP Reaction & + & + & + & + & + & + & + & + & + & + \\
\hline Citrate Utilization & + & + & - & + & - & - & - & - & + & - \\
\hline $\mathrm{H}_{2} \mathrm{~S}$ Production & - & - & - & - & - & - & - & - & - & - \\
\hline Urease Activity & - & - & - & - & - & - & - & - & - & - \\
\hline \multicolumn{11}{|l|}{ Hydrolysis of : } \\
\hline Gelatin & - & + & - & - & - & - & - & - & - & - \\
\hline Starch & - & - & - & - & - & - & - & - & - & - \\
\hline Casein & - & + & - & - & - & - & + & - & - & - \\
\hline Lipid & + & + & + & + & + & + & + & + & + & + \\
\hline Tween 80 & + & + & + & + & + & + & + & + & + & + \\
\hline Nitrate reduction to nitrite & - & + & - & + & - & - & - & + & + & - \\
\hline \multicolumn{11}{|l|}{ Growth at/in: } \\
\hline $0.5 \% \mathrm{NaCl}$ & + & + & + & + & + & + & + & + & + & + \\
\hline $3 \% \mathrm{NaCl}$ & + & + & + & + & + & + & + & + & - & + \\
\hline $5 \% \mathrm{NaCl}$ & + & + & - & + & - & - & + & - & - & - \\
\hline $4^{\circ} \mathrm{C}$ & - & - & - & - & - & - & - & - & - & - \\
\hline $25^{\circ} \mathrm{C}$ & + & + & + & + & + & + & + & + & + & + \\
\hline $37^{\circ} \mathrm{C}$ & + & + & + & + & + & + & + & + & + & + \\
\hline $55^{\circ} \mathrm{C}$ & - & - & - & w & - & $\mathrm{w}$ & $\mathrm{w}$ & $\mathrm{w}$ & $\mathrm{w}$ & - \\
\hline \multicolumn{11}{|l|}{ Growth on pH: } \\
\hline 3 & - & - & + & - & - & - & - & - & - & - \\
\hline 5 & - & + & + & ++ & - & ++ & - & - & + & ++ \\
\hline 8 & +++ & ++ & +++ & ++ & +++ & +++ & ++ & ++ & +++ & + \\
\hline 10 & + & + & + & + & + & + & ++ & - & +++ & - \\
\hline \multicolumn{11}{|l|}{ Carbon source: } \\
\hline Glucose & $+(\mathrm{A})$ & - & - & - & - & - & - & - & - & - \\
\hline Galactose & - & - & - & $+(\mathrm{A})$ & - & $+(\mathrm{A})$ & $+(\mathrm{A})$ & - & - & - \\
\hline Fructose & - & - & - & - & - & - & - & - & - & - \\
\hline Mannose & - & - & - & - & - & - & - & - & - & - \\
\hline Arabinose & - & - & - & - & - & - & - & - & - & - \\
\hline Sucrose & - & - & - & - & - & - & - & - & - & - \\
\hline Malto se & - & - & - & - & - & - & - & - & - & - \\
\hline Lactose & - & - & - & - & - & - & - & - & - & - \\
\hline
\end{tabular}

Note: (-): negative result; (+): positive result; (++): high growth; $(+++)$ : extremely high growth; (w): weak growth; (A) Acid production; (MR): methyl red;(VP): Voges-Proskauer; (Isolates 1-10): SKCSH1-SKCSH10

concentrations in the range of $0.5-5 \%(\mathrm{w} / \mathrm{v})$. All strains were able to grow at $\mathrm{NaCl}$ levels of $0.5-3 \% \mathrm{NaCl}$ (optimum $1 \% \mathrm{NaCl}$ ), except for strain SKCSH9 which did not grow at $3 \% \mathrm{NaCl}$. Moreover, no growth occured at concentrations greater than $3 \%$, with the exception of strains SKCSH1, SKCSH2, SKCSH4, and SKCSH7. 
Table 4 Mercury-resistant bacterial strains isolated from the Bunikasih traditional gold mine, Pangalengan, West Java Province, Indonesia

\begin{tabular}{lccc}
\hline \multicolumn{1}{c}{ Sampling sites } & Strain & Species & Sequence similarity (\%) \\
\hline Tailing Soil & SKCSH1 & Pseudomonas moraviensis & 96.96 \\
Sediment II & SKCSH2 & Stenotrophomonas africana & 99.69 \\
Sediment III & SKCSH3 & Pseudomonas plecogossicida & 97.57 \\
Sediment IV & SKCSH4 & Pseudomonas plecogossicida & 94.53 \\
Sediment IV & SKCSH5 & Pseudomonas plecogossicida & 98.66 \\
Sediment IV & SKCSH6 & Pseudomonas hibiscicola & 99.97 \\
Sediment IV & SKCSH7 & Pseudomonas plecogossicida & 96.61 \\
Sediment II & SKCSH8 & Aeromonas hydrophila subsp. ranae & 99.43 \\
Sediment IV & SKCSH9 & Pseudomonas plecogossicida & 96.73 \\
Sediment IV & SKCSH10 & Pseudomonas hibiscicola & 99.97 \\
\hline
\end{tabular}

The name of bacterial strains was a result of $16 \mathrm{~S}$ rRNA sequencing analysis.

All strains grew at 25 and $37^{\circ} \mathrm{C}$, with no or weak growth at $55{ }^{\circ} \mathrm{C}$. Most strains grew over a $\mathrm{pH}$ range of $5-10$ (optimum $\mathrm{pH} 7-8$ ), but none of strains did grew at $\mathrm{pH} 3$ (below $\mathrm{pH}$ 5) with the exception of strain SKCSH3. In addition, all strains were incapable of producing acid from the oxidation or the fermentation of the following carbohydrates: gluclose, galactose, fructose, mannose, arabinose, sucrose, maltose and lactose. However, some strains had the ability to produce acid from oxidation or fermentation of glucose (SKCSH1) and galactose (SKCSH4, SKCSH6, SKCSH7).

Phylogenetic Analysis of Hg-Resistant Bacteria. In order to identify the bacterial isolates, their $16 \mathrm{~S}$ rRNA genes were amplified and sequenced. Strain SKCSH1 was affiliated to Pseudomonas moraviensis (96.96\% similarity), strain SKCSH2 to Stenotrophomonas africana (99.69\% similarity), strains SKCSH3, SKCSH4, SKCSH5, SKCSH7, SKCSH9 to Pseudomonas plecogossicida $(97.57 \%$, 94.53\%, 98.66\%, 96.61\%, 96.73\% similarity, respectively), strains SKCSH6 and SKCSH10 to Pseudomonas hibiscicola (99.97\% similarity), and strain SKCSH8 to Aeromonas hydrophila subsp. ranae (99.43\% similarity) (Table 4). In an inferred phylogenetic tree, these three novel species (SKCSH4, SKCSH7, SKCSH9) together with our two other bacterial strains (i.e., SKCSH3 and SKCSH5) formed one distinct phylogenetic which was distantly related to recognizable species of the genus Pseudomonas, with Pseudomonas plecogossicida as the closest relative (Fig 1). The 16S rRNA gene sequences of each of the five strains were more similar to each other (>99\%) than to any other sequence in GenBank. In addition, strain SKCSH1 branched off most distantly and placed this strain within the genus Pseudomonas with Pseudomonas moraviensis as its closest neighbour. The
16S rRNA gene sequences of strains SKCSH6 and SKCSH10 all had the signature nucleotides and nucleotide pairs to indicate that they belonged to the family Pseudomonadaceae. The 16S rRNA gene sequences from strains SKCSH6 and SKCSH10 were almost $100 \%$ identical to each other, and were $99.97 \%$ identical to that of Pseudomonas hibiscicola. Phylogenetic analyses placed these two bacteria in a group that included our other $\mathrm{Hg}$-resistant bacterial strain (SKCSH2), Pseudomonas hibiscicola, Pseudomonas geniculata, Stenotrophomonas maltophilia and Stenotrophomonas africana (Fig 2). Strain SKCSH2 belonged to the family Xanthomonadaceae and the 16S rRNA gene sequence of this strain was $99.69 \%$ identical to that of Stenotrophomonas africana. These three bacteria (strains SKCSH2, SKCSH6 and SKCSH10) grouped together with more than $99 \%$ similarity. In addition, strain SKCSH8 formed a distinct phylogenetic group of the family Aeromodaceae within the genus Aeromonas with Aeromonas hydrophila subsp. ranae as its closest neighbour (99.43\% sequence similarity) (Fig 3).

\section{DISCUSSION}

All $\mathrm{Hg}$ levels in samples taken were above the maximum permissible concentration of $\mathrm{Hg}$ in sediments and soils of $0.04 \mathrm{mg} \mathrm{L}^{-1}$ (Swedish Environmental Protection Agency 1967), while the maximum permitted $\mathrm{Hg}$ concentration in water is 0.005 mg L ${ }^{-1}$ (Government Decree of the Republic of Indonesia No. 82, 2001). Hence, methods for cleaning up mercury-polluted environments in a cost-effective way are urgently required, since mercury is a highly toxic metal. Thus, by finding the mercury-resistant bacteria in this study, they might be beneficial to be 


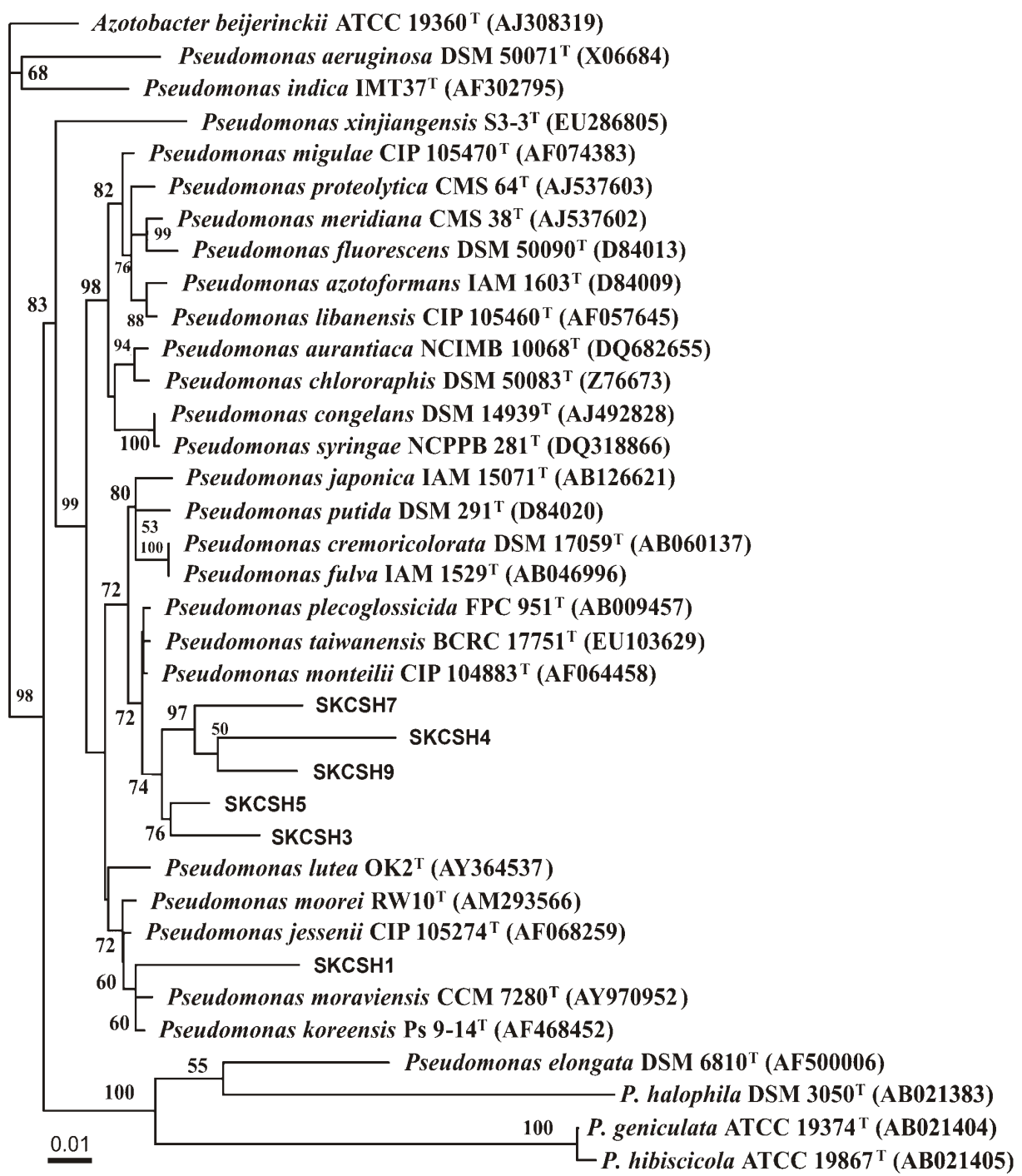

Fig 1 Phylogenetic tree of strains SKCSH1, SKCSH3, SKCSH4, SKCSH5, SKCSH7, and SKCSH9, based on 16S rRNA gene sequences. The branching pattern was produced by the neighbour-joining method. Numbers at nodes are percentage bootstrap values based on 1000 iterations; only values above $50 \%$ are shown. GenBank accession numbers are given in parentheses. Bar, 1 substitutions per 100 nucleotides.

biological agents for environmental applications. Application of these bacteria to mercury-polluted environments may lead to a potential cleanup technology which may be capable of bioremediating soil, water, or sediments contaminated with mercury in an environmentally friendly way. The role of the bacteria in mercury bioremediation is likely to have high levels of efficacy due to their mer operon-based resistance mechanism, which functions by active enzymatic reduction of mercury ions to water-insoluble metallic mercury (Vetriani et al. 2005; Omichinski 2007; Poulain et al. 2007). Therefore, further investigation of these bacterial mercury resistance is greatly needed in an effort to develop environmentally friendly, cost-effective bioremediation technology in Indonesia. Correspondingly, current environmental issues regarding mercury contamination in Indonesia are due to the illegal mining of gold using the amalgam process in which mercury is employed. Both wastewater and waste produced in the amalgam process were discharged into rivers, where mercury can be persistent over long periods of time, which in turn is a risk to humans because of its accumulation in the food chain (Laperdina 2002; Gustin et al. 2003; Wang et al. 2004; Kelly et al. 2006). The persistence of mercury in these mining disposals would enable us to acquire a high diversity of mercury-resistant bacteria. From the sediment and tailing soil samples of the Bunikasih River from which our mercury-resistant bacteria were isolated, ten heterotrophic bacteria were isolated with their level of resistance to mercury $\left(\mathrm{HgCl}_{2}\right)$ of $60-550$ $\mathrm{mg} \mathrm{L}^{-1}$ (Table 2). Their mercury resistance, which was over the $\mathrm{Hg}$ concentrations of the samples (27.6-60.7 $\mathrm{mg} \mathrm{L}^{-1}$ ) (Table 1), indicates that the bacteria might have adapted to mercury accumulated in sediments of the Bunikasih River for a long period of time due to their 


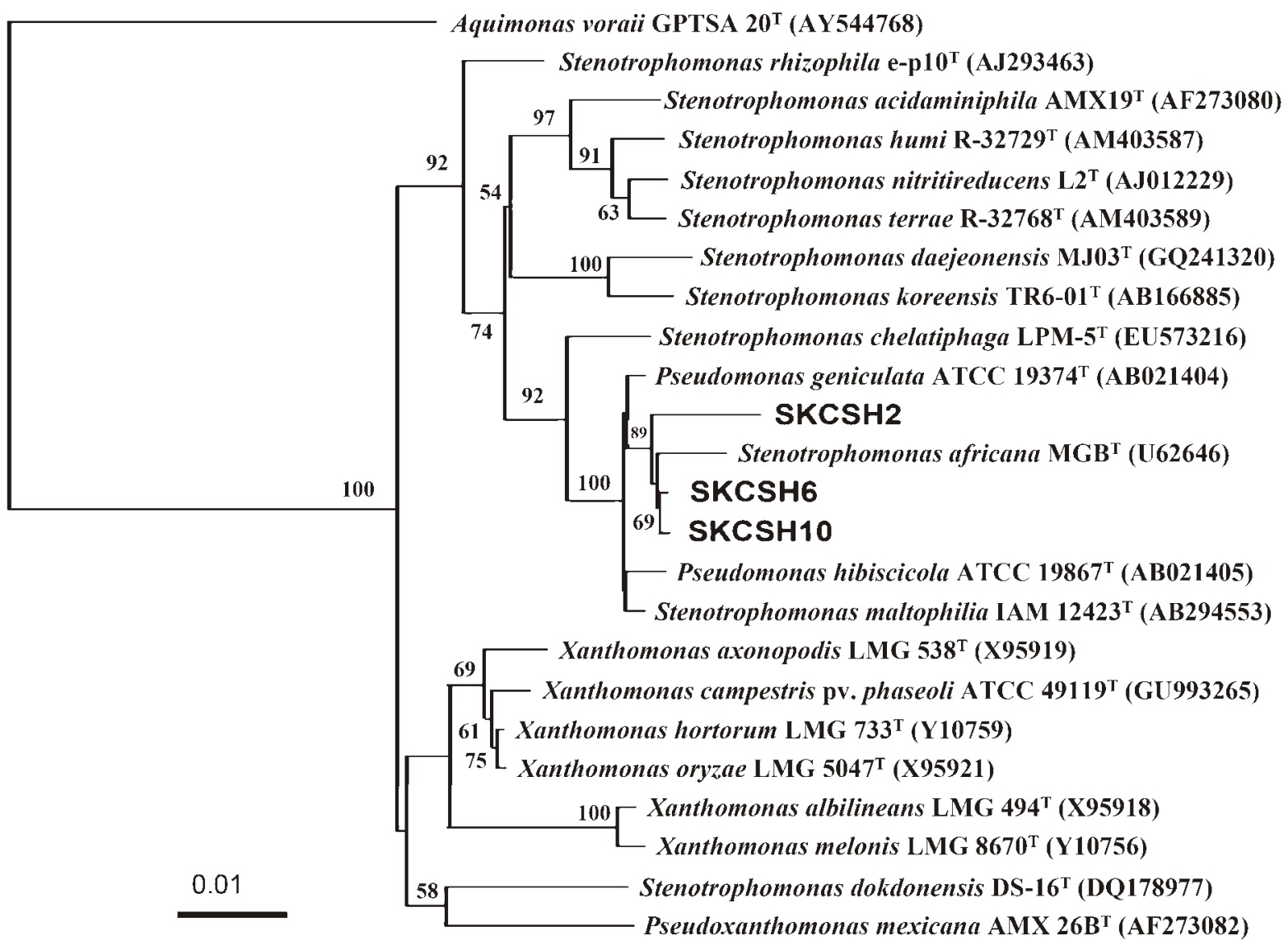

Fig 2 Phylogenetic tree of strains SKCSH2, SKCSH6, and SKCSH10, based on 16S rRNA gene sequences. The branching pattern was produced by the neighbour-joining method. Numbers at nodes are percentage bootstrap values based on 1000 iterations; only values above 50\% are shown. GenBank accession numbers are given in parentheses. Bar, 1 substitutions per 100 nucleotides.

superior traits (i.e. a high and constitutive expression of the mercury resistance genes) (Omichinski 2007). In MIC experiments (Table 2), the bacterial strains were grown on LB medium containing ionic mercury $\left(\mathrm{HgCl}_{2}\right)$, where their growth greatly depended on the $\mathrm{Hg}$ (II) bioavailability and toxicity. Nutrients in LB medium that contained sulfhydryl group (i.e. yeast extract) and a negatively charged ion (i.e. chloride) which binds to ionic mercury, thus altering its bioavailability and toxicity (Essa et al. 2002; Barkay et al.2003). Therefore, the ability to grow in the presence of mercury has been demonstrated here to be a important feature of mercury-resistant cells for the application in bioremediation processes.

The 16S rRNA gene sequence analysis revealed that ten mercury-resistant bacterial strains were identified as Pseudomonas spp., Stenotrophomonas sp., and Aeromonas sp. (Table 4). To date, the genera Pseudomonas, Stenotrophomonas and Aeromonas comprise 198, 13 and 30 species, respectively, with validly published names, at the time of writing (List of Prokaryotic Names with Standing in Nomenclature
(LPSN); http://www.bacterio.cict.fr/). Of the ten bacterial strains, eight strains were identified as Pseudomonas that was predominant within the $\mathrm{Hg}$ resistant bacterial diversity in the sites (Table 4). The dominance of the genus Pseudomonas is not surprising, since the genus Pseudomonas has been recognized for its ability to utilize a broad spectrum of environmental pollutants such as organics and heavy metals (Tvrzova et al. 2006). The genus Pseudomonas is also known as a large and widely diverse bacterial group and members of the genus Pseudomonas are ubiquitous in a wide variety of habitats such as soil, water and sediments (Young and Park 2007). Of the members of the genus Pseudomonas, Pseudomonas plecoglossicida predominated in all samples (sediments III and IV) from which five strains of $P$. plecoglossicida were successfully isolated (Table 4). The species $P$. plecoglossicida has been reported to be a causative agent of fish disease (Nishimori et al. 2000). Two other Pseudomonas species were also obtained in this study; two strains of the species Pseudomonas hibiscicola from sediment IV sample and one strain of the species 


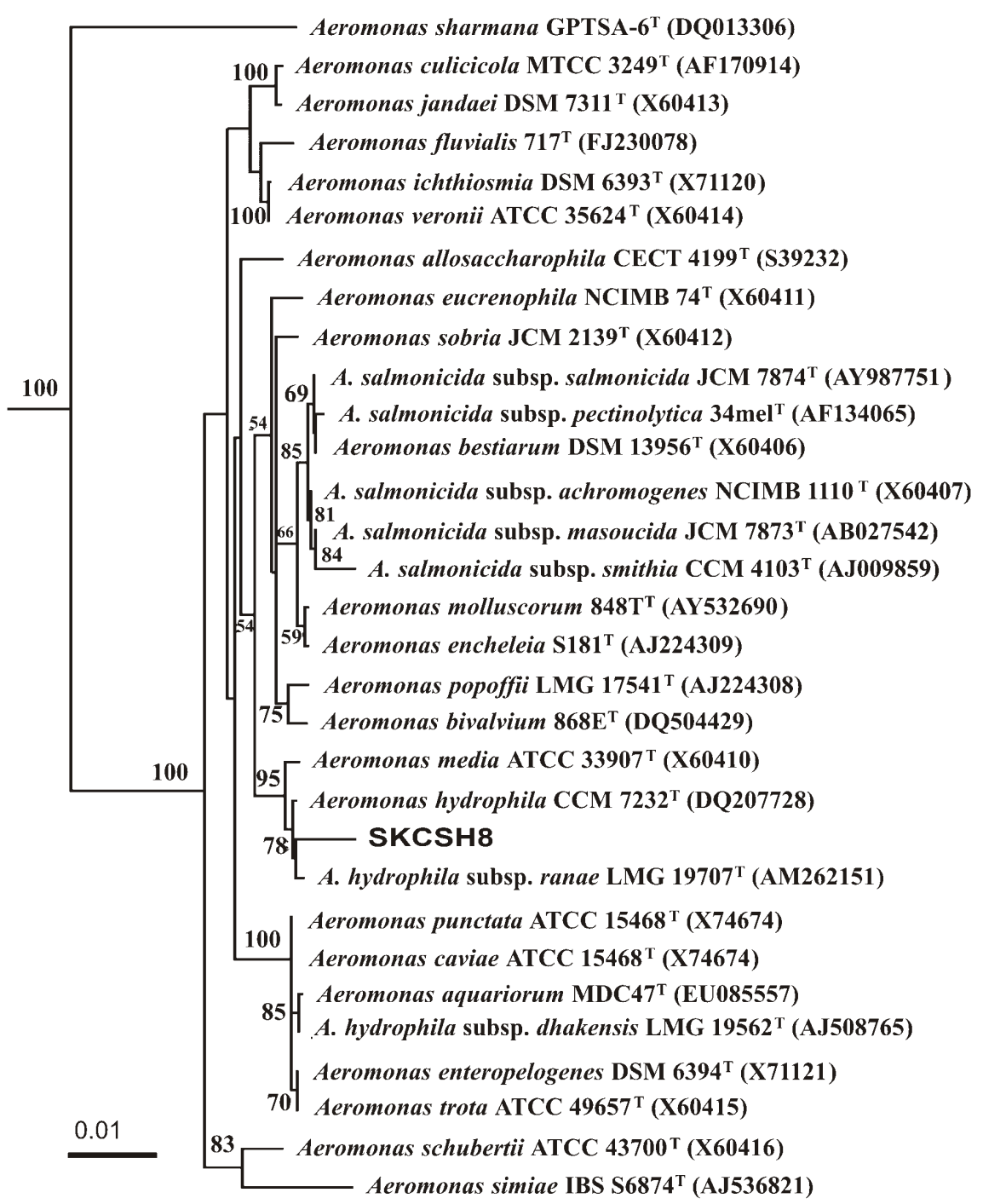

Fig 3 Phylogenetic tree of strain SKCSH8, based on 16S rRNA gene sequences. The branching pattern was produced by the neighbour-joining method. Numbers at nodes are percentage bootstrap values based on 1000 iterations; only values above $50 \%$ are shown. GenBank accession numbers are given in parentheses. Bar, 1 substitutions per 100 nucleotides.

Pseudomonas moraviensis from tailing soil sample (Table 4). The first strain of the species $P$. moraviensis was isolated from soil contaminated with nitroaromatis in Moravia, in the Czech Republic (Tvrzova et al. 2006).

In addition to the genus Pseudomonas, one species of the genus Aeromonas (i.e., Aeromonas hydrophila subsp. ranae) was also recovered from sediment II sample (Table 4). Members of the genus Aeromonas have been recognized as opportunistic human pathogens, and strains of Aeromonas hydrophila are also pathogenic to amphibians (Huys et al. 2003). They are also widely distributed in freshwater environments (Holmes et al. 1996) and some strains of Aeromonas hydrophila are reported to be resistant to heavy metals (Miranda and Castillo 1998). Apart from the genera Pseudomonas and Aeromonas, one member of the genus Stenotrophomonas (i.e., Stenotrophomonas africana) was present in the sediment II sample (Table 4). The genus Stenotrophomonas was created in 1993 to accommodate Xanthomonas maltophila (formerly Pseudomonas maltophila) (Palleroni and Bradbury 1993), and Stenotrophomonas africana is a later synonym of Stenotrophomonas maltophila (Coenye et al. 2004). The species $S$. africana is an essensial cause of nosocomial infection that is present in a wide range of environmental niches (Drancourt et al. 1997). The genus Stenotrophomonas is frequently found in soils and especially in the plant rhizospheres which are particularly contaminated with potentially toxic metals such as copper, platinum, mercury, gold, cadmium, lead, chromium, silver, and selenium salts (Barkay et al.2003).

Although large numbers of the genus Pseudomonas are capable of being resistant to mercury, they are not representatives of the type strains of mercury-resistant 
bacteria. Until presently, there are only two type strains of mercury-resistant bacteria in the world which were Alteromonas tagae sp. nov. (type strain $\mathrm{AT} 1^{\mathrm{T}}=\mathrm{BCRC}$ $17571^{\mathrm{T}}$-JCM $13895^{\mathrm{T}}$ ) and Alteromonas simiduii sp. nov. (type strain $\mathrm{AS1}^{\mathrm{T}}=\mathrm{BCRC} 17572^{\mathrm{T}}-\mathrm{JCM} 13896^{\mathrm{T}}$ ) isolated from water samples of the Er-Jen River estuary, Tainan, Taiwan (Chiu et al. 2007). Thus, our findings of Hg-resistant bacteria (Pseudomonas moraviensis strain SKCSH1 and Pseudomonas plecogossicida strains SKCSH4, SKCSH7, and SKCSH9) could be regarded as the type strains of four novel species in the genus Pseudomonas that will add to the diversity of $\mathrm{Hg}$ resistant bacteria worldwide. The distinct nature of their phylogenetic position suggests that these four isolates have the high possibility to be novel species of the genus Pseudomonas due to their 16S rRNA gene sequence similarities below 97\% (the threshold recognized as delineating a genospecies (Stackebrandt and Goebel 1994; Prakash et al. 2007; Tindall et al. 2010)).

In conclusion, the present study has provided the first evidence of the phylogenetically-diverse $\mathrm{Hg}$ resistant bacteria in the Hg-polluted sites of Indonesia in which the genus Pseudomonas predominates. Likewise, the bacteria are highly resistant to $\mathrm{Hg}$ concentrations $\left(\mathrm{HgCl}_{2}\right)$ of $60-550 \mathrm{mg} \mathrm{L} \mathrm{L}^{-1}$. Such information may prove highly useful for developing in situ bioremediation of $\mathrm{Hg}$-contaminated sites in Indonesia.

\section{ACKNOWLEDGEMENTS}

This work was supported by a grant from HIBAH DIKTI DIPAITB 2010, Indonesia. We also thank all the students of Laboratory of Biogeosciences, Mining and Environmental Bioengineering for their assistance and cooperation.

\section{REFERENCES}

Altschul SF, Gish W, Miller W, Myers EW, Lipman DJ. 1990. Basic local alignment search tool. J Mol Biol. 215(3): 403-410.

Ambers RKR, Hygelund BN. 2001. Contamination of two Oregon reservoirs by cinnabar mining and mercury amalgamation. Environ Geol. 40(6): 699-707.

Ariya PA, Peterson K, Snider G, Amyot M. 2009. Mercury chemical transformation in the gas, aqueous and heterogeneous phases: state-of-the-art science and uncertainties. In: Pirrone N, Mason R, editors. Mercury fate and transport in the global atmosphere. Springer. $\mathrm{p}$ 459-501.doi:10.1007/978-0-387-93958-2 7.
Ayhuan D, Atteng O, Dondokambey A, Randuk M. 2003. Mercury pollution on district of Dimembe river system, North Sulawesi, Indonesia, due to traditional gold mining activities. J Physique IV France. 107: 79-82.

Barkay T, Miller SM, Summers AO. 2003. Bacterial mercury resistance from atoms to ecosystems. FEMS Microbiol Rev. 27(2-3): 355-384.

Cappuccino JG, Sherman N. 2005. Microbiology: A Laboratory Manual. Massachusetts: Addison-Wesley Publishing Company. p 81-86.

Chaerun SK, Tazaki K, Asada R, Kogure K. 2004. Bioremediation of coastal areas 5 years after the Nakhodka oil spill in the Sea of Japan: Isolation and characterization of hydrocarbon-degrading bacteria. Environ Int. 30(7): 911-922.

Chiu HH, Shieh WY, Lin SY, Tseng CM, Chiang PW, WagnerDobler I. 2007. Alteromonas tagae sp. nov. and Alteromonas simiduii sp. nov., mercury-resistant bacteria isolated from a Taiwanese estuary. Int $\mathrm{J}$ Syst Evol Microbiol. 57(6):1209-1216.doi: doi:10.1099/ijs.0.64762-0.

Coenye T, Vanlaere E, Falsen E, Vandamme P. 2004. Stenotrophomonas africana Drancourt et al. 1997 is a later synonym of Stenotrophomonas maltophilia (Hugh 1981) Palleroni and Bradbury 1993. Int J Syst Evol Microbiol. 54(4):1235-1237.doi:10.1099/ijs.0.630930 .

DIN ISO 38414-S. 1983. Deutsche Einheitsverfahren zur Wasser-, Abwasser-, und Schlammuntersuchung; Schlamm und Sediment. Beuth, Berlin, Wien, Zurich.

DIN ISO 10390. 1997. Bestimmung des pH-Wertes. Beuth, Berlin, Vienna, Zurich.

Drancourt M, Bollet C, Raoult D. 1997. Stenotrophomonas africana sp. nov., an opportunistic human pathogen in Africa. Int J Syst Bacteriol. 47(1):160-163.

Dzairi FZ, Zeroual Y, Moutaouakkil A, Taoufik J, Talbi M, Loutfi M, Lee K, Blaghen M. 2004. Bacterial volatilization of mercury by immobilized bacteria in fixed and fluidized bed reactors. Annals Microbiol. 54(4): 353-364

Essa AMM, Macaskie LE, Brown NL. 2002. Mechanisms of mercury bioremediation. Biochem Society Transactions. 30(4): 672-674.

Fantozzi L, Ferrara R, Frontini FP, Dini F. 2009. Dissolved gaseous mercury production in the dark: Evidence for the fundamental role of bacteria in different types of Mediterranean water bodies. Sci Total Environ. 407: 917-924.

Felsenstein J. 1985. Confidence limits on phylogenies: an approach using the bootstrap. Evolution 39(4): 783791.

Garcia-Sanchez A, Contreras F, Adams M, Santos F. 2006. Atmospheric mercury emissions from polluted mining areas (Venezuela). Environ Geochem Health. 28(6): 529-540.doi: 10.1007/s10653-006-9049-x.

Government Decree of the Republic of Indonesia No. 82. 2001. Water Quality Management and Water Pollution Control. Jakarta, Indonesia.

Green-Ruiz C. 2006. Mercury (II) removal from aqueous 
solutions by nonviable Bacillus sp. from a tropical estuary. Bioresource Technol. 97(15):1907-1911.

Gustin MS, Coolbaugh MF, Engle MA, Fitzgerald BC, Keislar RE, Lindberg SE, Nacht DM, Quashnick J, Rytuba JJ, Sladek C, Zhang H, Zehner RE. 2003. Atmospheric mercury emissions from mine wastes and surrounding geologically enriched terrains. Environ Geology. 43(3): 339-351.doi:10.1007/s00254-0020630-z.

Gustin MS, Stamenkovic J. 2005. Effect of watering and soil moisture on mercury emissions from soils. Biogeochem. 76(2): 215-232.doi:10.1007/s10533-0054566-8.

Holmes P, Niccolls LM, Sartory DP. 1996. The ecology of mesophilic Aeromonas in the aquatic environment. In: Austin B, Altwegg M, Gosling PJ, Joseph S, editors. The Genus Aeromonas. Chichester: Wiley. p 127-150.

Huys G, Pearson M, Kämpfer P, Denys R, Cnockaert M, Inglis V, Swings J. 2003. Aeromonas hydrophila subsp. ranae subsp. nov., isolated from septicaemic farmed frogs in Thailand. Int J Syst Evol Microbiol. 53(3): 885891.doi:10.1099/ijs.0.02357-0.

Kelly D, Budd K, Lefebvre DD. 2006. Mercury analysis of acid- and alkaline-reduced biological samples: Identification of meta-cinnabar as the major biotransformed compound in algae. Appl Environ Microbiol. 71(1): 361-367.doi:10.1128/AEM.72.1.361367.2006 .

Laperdina TG. 2002. Estimation of mercury and other heavy metal contamination in traditional gold-mining areas of Transbaikalia. Geochem Exploration Environ Anal. 2(3): 219-223.

Lecce S, Robert P, Gwenda S. 2007. Mercury contamination of active channel sediment and floodplain deposits from historic gold mining at Gold Hill, North Carolina, USA. Environ Geol. 55(1): 113-121.

Mason RP. 2009.Mercury emissions from natural processes and their importance in the global mercury cycle. In: Pirrone N, Mason R, editors. Mercury Fate and Transport in the Global Atmosphere. Springer p 173191.doi:10.1007/978-0-387-93958-2_7.

Miller JR, Lechler PJ. Bridge G. 2003. Mercury contamination of alluvial sediment within the Essequibo and Mazaruni river basins, Guyana. Water Air Soil Poll. 148 (1-4):139-166.

Miranda CD, Castillo G. 1998. Resistance to antibiotic and heavy metals of motile aeromonads from Chilean freshwater. Sci Total Environ. 224(1-3):167-176.

Nascimento AMA, Chartone-Souza E. 2003. Operon mer: Bacterial resistance to mercury and potential for bioremediation of contaminated environments. Gen Mol Res. 2(1): 92-101.

Ni Chadhain SM, Schaefer JK, Crane S, Zylstra GJ, Barkay T. 2006. Analysis of mercuric reductase (merA) gene diversity in an aerobic mercury-contaminated sediment enrichment. Environ Microbiol. 8(10):1746-1752. doi:10.1111/j.1462-2920.2006.01114.x.

Nishimori E, Kita-Tsukamoto K, Wakabayashi H. 2000. Pseudomonas plecoglossicida sp. nov., the causative agent of bacterial haemorrhagic ascites of ayu, Plecoglossus altivelis. Int J Syst Evol Microbiol. 50: 8389.

Omichinski JG. 2007. Toward methylmercury bioremediation. Science 317:205-206.

Palleroni NJ, Bradbury JF. 1993. Stenotrophomonas, a new bacterial genus for Xanthomonas maltophilia (Hugh 1980). Int J Syst Bacteriol. 43(3): 606-609.

Poulain AJ, Ni Chadhain SM, Ariya PA, Amyot M, Garcia E, Campbell PGC, Zylstra GJ, Barkay T. 2007. Potential for mercury reduction by microbes in the high arctic. Appl Environ Microbiol. 73(7):2230-2238.doi:10.1128/AEM.02701-06.

Prakash O, Verma M, Sharma P, Kumar M, Kumari K, Singh A, Kumari H, Jit S, Gupta SK, Khanna M, Lal R. 2007. Polyphasic approach of bacterial classification-an overview of recent advances. Indian J Microbiol. 47(2): 98-108.

Saitou N, Nei M. 1987. The neighbor-joining method: a new metod for reconstructing phylogenetic trees. Mol Biol Evol. 4(4): 406-425.

Stackebrandt E, Goebel BM. 1994. Taxonomic note: A place for DNA-DNA reassociation and 16S rRNA sequence analysis in the present species definition in bacteriology. Int J Syst Evol Microbiol. 44(4): 846-849.

Swedish Environmental Protection Agency. 1967. Sediment Quality Guidelines, Sweden.

Swofford DL. 2002. PAUP*: Phylogenetic analysis using parsimony (*and other methods). Sinauer Associates, Sunderland, Massachusetts, USA.

Thompson JD, Higgins DG, Gibson TJ. 1994. CLUSTAL W: Improving the sensitivity of progressive multiple sequence alignment through sequence weighting, position-specific gap penalties and weight matrix choice. Nucleic Acids Res. 22(22): 4673-4680.

Tian L, Guo HF, Gao A, Lu XT. 2009. Effects of mercury released from gold extraction by amalgamation on renal function and environment in Shanxi, China. Bull Environ Contam Toxicol. 83(1): 71-74. doi:10.1007/ s00128-009-9722-8.

Tindall BJ, Rossello-Mora R, Busse HJ, Ludwig W, Kampfer P. 2010. Notes on the characterization of prokaryote strains for taxonomic purposes. Int $\mathrm{J}$ Syst Evol Microbiol. 60(1): 249-266.doi:10.1099/ijs.0.016949-0.

Tvrzova L, Schumann P, Sproer C, Sedlacek I, Pacova Z, Sedo O, Zdrahal Z, Steffen M, Lang E. 2006. Pseudomonas moraviensis sp. nov. and Pseudomonas vranovensis sp. nov., soil bacteria isolated on nitroaromatic compounds, and emended description of Pseudomonas asplenii. Int J Syst Evol Microbiol. 56(11): 2657-2663.doi:10.1099/ijs.0.63988-0.

US Environmental Protection Agency (US EPA). 2003. Mercury research multi-year plan. FY 2005 Planningfinal version. Office of Research and Development, Washington DC, USA.

Vetriani C, Chew YS, Miller SM, Yagi J, Coombs J, Lutz RA, Barkay T. 2005. Mercury adaptation among bacteria from a deep-sea hydrothermal vent. Appl Environ 
Microbiol. 71(1): 220-226. doi:10.1128/AEM.71.1.220226.2005 .

Wagner-Dobler I. 2003. Pilot plant for bioremediation of mercury-containing industrial wastewater. Appl Microbiol Biotechnol. 62(2-3): 124-133. doi:10.1007/ s00253-003-1322-7.

Wang Q, Kim D, Dionysios DD, Sorial GA, Timberlake D. 2004. Sources and remediation for mercury contamination in aquatic systems a literature review. Environ Poll. 131(2):323-336.

Yang Y, Chen H, Wang D. 2009. Spatial and temporal distribution of gaseous elemental mercury in Chongqing, China. Environ Monit Assess. 156(14):479-489.doi:10.1007/s10661-008-0499-8.
Young JM, Park DC. 2007. Probable synonymy of the nitrogen-fixing genus Azotobacter and the genus Pseudomonas. Int J Syst Evol Microbiol. 57(12):28942901.doi:10.1099/ijs.0.64969-0.

Zhu W, Fu X, Feng X, Lu JY. 2008. Annual time-series analyses of total gaseous mercury measurement and its impact factors on the Gongga Mountains in the southeastern fringe of the Qinghai-Tibetan Plateau. J Mountain Sci. 5(1): 17-31. doi:10.1007/s11629-0080017-z. 